\title{
Electrolytic treatment of latex wastewater
}

\begin{abstract}
A novel method of latex wastewater treatment was developed based on in-situ hypochlorous acid generation. The hypochlorous acid was generated in an undivided electrolytic cell consisting of two sets of graphite as anode and stainless sheets as cathode. The generated hypochlorous acid served as an oxidizing agent to destroy the organic present in the latex wastewater. For an influent COD concentration of 3,820 mg/L at an initial $\mathrm{pH} \mathrm{4.5}$; current density of $74.5 \mathrm{~mA} / \mathrm{cm} 2$; sodium chloride content $3 \%$ and electrolysis period of $90 \mathrm{~min}$, resulted in the following residual concentration pH 7.3; COD $78 \mathrm{mg} / \mathrm{L}$; BOD5 $55 \mathrm{mg} / \mathrm{L}$; TOC $45 \mathrm{mg} / \mathrm{L}$; residual total chlorine $136 \mathrm{mg} / \mathrm{L}$; turbidity $17 \mathrm{NTU}$ and temperature $54^{\circ} \mathrm{C}$, respectively. In the case of $2 \%$ sodium chloride content for the above, said operating condition resulted in a residual concentration of $\mathrm{pH}$ 7; COD $162 \mathrm{mg} / \mathrm{L}$; BOD5 $105 \mathrm{mg} / \mathrm{L}$; TOC $90 \mathrm{mg} / \mathrm{L}$; residual total chlorine $122 \mathrm{mg} / \mathrm{L}$; turbidity $26 \mathrm{NTU}$ and temperature $60^{\circ} \mathrm{C}$ respectively. The energy requirements were found to be 35 and $50 \mathrm{Wh} / \mathrm{L}$ while treating $24 \mathrm{~L}$ of latex wastewater at 3 and $2 \%$ sodium chloride concentration at a current density 74.5 $\mathrm{mA} / \mathrm{cm} 2$. The observed energy difference was due to the improved conductivity at high sodium chloride content.
\end{abstract}

Keyword: Electrolytic treatment; Latex wastewater; Hypochlorous acid; Chlorine; Rubber wastewater; Electrochemical treatment 